DOI: https://doi.org/10.15407/mzu2020.29.201

UDC 94(438)[437.7:327]“1938/1939”

Mykola Vehesh

Doctor of History, Professor

Head of Department

Uzhhorod National University

3, Narodna Square, Uzhhorod, 88000, Ukraine

E-mail: f-history@uzhnu.edu.ua

ORCID: https://orcid.org/0000-0002-1848-8839

Stepan Vidnyanskyj

Doctor of History, Professor, Corresponding Member of the National Academy of Sciences of Ukraine Head of the Department of the History of International Relations and Foreign Policy of Ukraine Institute of History of Ukraine the National Academy of Sciences of Ukraine 4, Mykhailo Hrushevskyi Street, Kyiv, 01001, Ukraine

E-mail: stepanvid@ukr.net ORCID: https://orcid.org/0000-0002-8825-7024

\title{
SOME ASPECTS OF STATE-BUILDING PROCESSES IN CARPATHIAN UKRAINE ON THE EVE OF THE SECOND WORLD WAR
}

Autonomous Subcarpathian Rus', and subsequently independent Carpathian Ukraine, existed for an extremely short period of time: from October 1938 to the second half of March, 1939. Despite this fact, there was such a rapid development of political events in the country that the attention of the whole world was drawn to Carpathian Ukraine. This also applies to the researchers who, at the end of the 1930s, began to study the history of Carpathian Ukraine.

The declaration of independence on March 14, 1939 was explained by the desire of the Ukrainian population of the region for freedom. However, the disintegration of Czechoslovakia and the declaration of independence by Slovakia were also of great importance for this act. Despite some spontaneity and haste, this historical event in the life of not only Transcarpathian Ukrainians, but of the entire Ukrainian people was of great historical importance. After January 21, 1919, it was the second attempt to declare to the 
whole world that Ukrainian nation is alive and ready for state life. Although this act of declaration of independence, ratified on March 15, 1939 at the Soim of Carpathian Ukraine, was more symbolic than real politics, it played a large role in forming the self-consciousness of the entire Ukrainian nation. It was during the period of Carpathian Ukraine that a kind of transition from consciousness of Transcarpathian Ruthenians to Transcarpathian Ukrainians ended.

In the late 1930s, Carpathian Ukraine was the only state where a small branch of the Ukrainian people proclaimed their independence and declared their desire to live a state life. The Ukrainians who were part of the USSR, as well as the Ukrainians under the control of Poland and Romania didn't have such opportunity. However, they treated Carpathian Ukraine as an area where an attempt was made to restore Ukrainian statehood. On this basis, it is necessary to consider the formation of the Carpatho-Ukrainian state as the second stage - after the liberation contest of 1918-20's - in the struggle for the creation of Ukrainian state formation on a separate Ukrainian territory.

Keywords: Carpathian Ukraine, Avgustyn Voloshyn, Soim, autonomous governments, state-building processes, political elections, political crisis, UNO, Carpathian Sich.

Микола Вегеш

д-р. іст. наук, проф., зав. каф. Ужгородський національний університет 88000 , Україна, Ужгород, пл. Народна, 3 E-mail: f-history@uzhnu.edu.ua ORCID: https://orcid.org/0000-0002-1848-8839

\section{Степан Віднянський}

д-р. іст. наук, проф., чл.-кор. НАН України зав. від. історії міжнародних відносин і зовнішньої політики України 01001, Україна, Київ, вул. Михайла Грушевського, 4 E-mail: stepanvid@ukr.net ORCID: https://orcid.org/0000-0002-8825-7024

\section{ДЕЯКІ АСПЕКТИ ДЕРЖАВОТВОРЧИХ ПРОЦЕСІВ У КАРПАТСЬКІЙ УКРАЇНІ НАПЕРЕДОДНІ ДРУГОЇ СВІТОВОЇ ВІЙНИ}

Автономна Підкарпатська Русь, а згодом самостійна Карпатська Україна, існувала впродовж надзвичайно короткого відтинку часу: з 
жовтня 1938 р. до другої половини березня 1939 р. Незважаючи на щее, у краї відбувався такий бурхливий розвиток політичних подій, щзо до Карпатської України була прикута увага всієї світової громадськості. Це стосується $і$ дослідників, які вже наприкінщі 30-х років почали звертатися до вивчення історії Карпатської України. Проголошення незалежності 14 березня 1939 р. пояснювалося прагненням украӥнського населення краю до свободи. Однак, важливе значення в поспішності изього акту мав розпад Чехословаччини і проголомення самостійності Словаччиною. Попри деяку спонтанність і поспішність, ия історична подія в житті не тільки закарпатських українців, але $і$ всього українського народу мала велике історичне значення. Це була друга, після 21 січня 1919 р., спроба заявити перед иілим світом, щяо українська нація живе й готова до державного життя. I хоча цей акт проголошення незалежності, ратифікований 15 березня 1939 р. на Соймі Карпатської Украӥни, був більше символічним, ніж реальною політикою, він відіграв важливу роль у формуванні самосвідомості всієї української нації. Саме в період існування Карпатської України завершився своєрідний перехід у сфері свідомості від підкарпатських русинів до закарпатських украӥнців.

Наприкіниі 30-х років Карпатська Україна виявилася єдиною державою, де невелика гілка українського народу проголосила свою незалежність $i$ заявила про бажання жити державним життям. Такої можсливості не мали ні українці, які перебували у складі СРСР, ні украӥнці під владами Польщчі та Румунії. Однак, вони дивилися на Карпатську Україну як на територію, де здійснюється спроба відновити украӥнську державність. Виходячи з изього, необхідно розцінювати утворення Карпато-української держави як другий, після визвольних змагань 1918-20-х років, етап у боротьбі за створення украӥнського державного утворення на окремо взятій українській території.

Ключові слова: Карпатська Украӥна, Августин Волошин, Сойм, автономні уряди, державотворчі прочеси, політичні вибори, політична криза, УНО, Карпатська Січ.

The formation of the Carpatho-Ukrainian state was the result of many years of activity of the Ukrainian patriotic forces in all spheres of social and political life. However, we should mention that the short-lived existence of an autonomous, and subsequently independent Transcarpathian region (Subcarpathian Rus', Carpathian Ukraine) coincided with the acute political crisis in Central Europe that took place on the eve of World War II. Naturally, the international factor made its mark on the socio-political processes that took place in Europe in general, and in Czechoslovakia and Transcarpathia, as an integral part of it, in particular. Despite the complexity of the international 
situation at that time, Transcarpathia won the autonomous rights and built its statehood in alliance with the Czechs and Slovaks.

Clarification of these and some other problems, an objective and comprehensive study of the place and role of Carpathian Ukraine in the context of the Central European political crisis before the Second World War deserves special research. The situation of Carpathian Ukraine in the late 1930s should be considered in two respects: as a subject of political processes that took place in Central Europe on the eve of World War II, and as one of the stages of the struggle of Ukrainian people for the restoration of their statehood, taking into account such fact that here we can talk only about a separate part of the Ukrainian lands.

Twenty years of being a part of the democratic Czechoslovak Republic has created optimal conditions for the diverse national and cultural development of Transcarpathia, though it is not necessary to idealize it. Owing to the active work of the Ukrainian parties, societies and individual socio-cultural figures, the national consciousness of the people in Transcarpathia grew up, the people who, in fact, underwent a peculiar evolution from the Hungarian Ruthenians to the Transcarpathian Ukrainians, to the self-awareness of their identity, to the idea of political unity with all Carpathian people.

Czechoslovakia's attitude to Transcarpathia and to the Ukrainian problem in general differed significantly from the policy on the Ukrainian idea of other European countries, especially Poland. This fact undoubtedly contributed to A. Voloshyn's clear Ukrainian course, albeit with a focus on German patronage, and the Transcarpathian autonomous governments received comprehensive support from Ukrainians in Eastern Galicia, European countries, the United States and Canada, who saw in that autonomous state the embryo of united Ukraine. Researching this problem has got an indisputably scientific meaning. The small branch of the Ukrainian people, having received material and moral support from the Ukrainian emigration, causing wonder all over the world, became able to carry out to some extent their own internal and foreign policy, which resulted in an attempt to form a Ukrainian statehood. This was not possible for the Ukrainians who were under the totalitarian regime in the USSR, who were in Poland and Romania.

The relevance of this study is also determined by the need to debunk the claims of modern neo-Ruthenian theorists who question the region's belonging to Ukraine. They deny in every way the regularity of the political processes that took place here in 1918-1919 and, especially in the late 1930s, they attempt to prove that the idea of independence of Carpathian Ukraine was brought to Transcarpathia from outside, in particular from Galicia. The sources from a number of national and foreign archives have arguably proved all the baselessness and pseudoscience character of such separatist interpretations. On 
the contrary, these sources convince that Carpathian Ukraine was a creation of local factors, although it was influenced by a number of international and internal factors.

On May 8, 1919 the Rus' Central People's Council in Uzhgorod decided to incorporate Transcarpathia into Czechoslovakia as an autonomy. This act fulfilled the requirement of the American Ruthenians, who on November 18, 1918, at their meeting in Scranton, called for the inclusion of the region into the Czechoslovak Republic. On November 18, 1919 I. Breich was appointed as a temporary administrator of Transcarpathia. According to the "General Charter", the Czechoslovak government was obliged to give the widest autonomous rights to Subcarpathian Rus', as the region was called at that time.

The Prague government was constantly delaying the fulfilment of its promises, arguing that the Transcarpathians had not yet "matured" to an independent life. The first stage of autonomy was realized only on October 8, 1938. It was the victory of all the political forces of the region, both Russophile and Ukrainian, who actively fought for autonomous rights throughout the interwar period. The end of September 1938 should be regarded as a decisive moment in the relationship of the above directions. It should be noted that as early as September 2, 1938, the representatives of Russophiles and Narodovtsi (Ukrainophiles) signed a declaration to which the Czechoslovak government did not respond. The requirements announced by E. Bachynsky included the incorporation of the Prešov region to Subcarpathian Rus', the provision of financial assistance to the Verkhovyna districts (mountain districts), and the personal replacement of the representatives in governmental institutions ${ }^{1}$.

On September 21, 1938 negotiations were held in Prague with participation of E. Bachynsky, I. Pieshchak, P. Kossey, S. Fentsyk, A. Brodi, Y. Feldeshiy, P. Zhydovsky, and Y. Revai. They were all members of the Czechoslovak Parliament ${ }^{2}$. At the same time, a delegation of American Ruthenians, consisting of I. Pop, I. Yanchyshyn, and O. Herovsky, visited Transcarpathia, and it "was supposed to help the parliamentary representatives of both groups to solve urgent political problems of the region. The delegation did not, however, represent the American Ruthenians of the Greek Catholics, who made up the majority of Ruthenians in the United States"3. That is why this delegation did not fulfil its tasks.

In early October 1938 negotiations between representatives of the two directions were resumed with the aim of creating an autonomous government of Subcarpathian Rus'. At a meeting on October 7, 1938 it was decided that only members of the Prague Parliament and the Senate could be members of the government. We must agree with V. Shandor's assertion that this was done "with the expectation of success in the government, because the Moscophiles were worried"4. On the same day, representatives of the Russophile bloc 
proposed a project of decentralization of state and executive power, which consisted of eight items. On October 8 a National Council of Subcarpathian Rus' was established in Uzhgorod, which included J. Kaminsky, V. Homichkov, M. Demko (Central People's Council of Rus'), A. Voloshyn, Y. Brashchayko, D. Nimchuk (First Ukrainian People's Council), A. Brodi, Y. Feldeshiy (Autonomous Agricultural Union), E. Bachynsky, P. Kossey (Republican Agricultural Party), S. Fentsyk (Rus' National-Autonomous Party), Y. Revai (Social Democratic Party), I. Pieszczak (Autonomous Agricultural Union of Prešov Region), P. Zhydovsky (Republican Agricultural Party of Prešov Region) ${ }^{5}$. Thus, the National Council of Subcarpathian Rus' included the representatives of all major political forces of the region.

At the first session of the Council, a Memorandum was adopted, which ended with a demand to immediately adopt a law on Subcarpathian Rus'. On October 8, 1938, Czechoslovakia's Prime Minister J. Syrovy dismissed K. Hrabar and appointed I. Parkanij as the governor of the land. The latter once again emphasized the main requirements of the National Council of Subcarpathian Rus'. Meanwhile, representatives of the two directions discussed candidates for the posts of ministers of Subcarpathian Rus'. Y. Revai proposed to invite three members from both councils. The proposition was accepted. The Ukrainian delegation was headed by A. Voloshyn, the Moscophiles delegation by J. Kaminsky.

At a joint meeting of the Rus' and Ukrainian Central People's Councils, proposals were made for the composition of the future government of Subcarpathian Rus": "At the meetings it was unanimously decided: to seek the same rights for Subcarpathian Rus' that were granted to Slovakia on the basis of the requirements added to this Protocol. It was further decided unanimously to propose Andriy Brodi for the Prime Minister and the Minister of National Education, Dr. Edmund Bachynsky for the Minister of Internal Affairs, Dr. Ivan Pieshchak for the Minister of Justice, Yulian Revai for the Minister of Communication, ie: railways, post and public works, Fr. Avgustyn Voloshyn for the Minister of Health and Social Welfare, Dr. Stepan Fentsyk for the Minister of Economic Affairs. It is decided to demand an immediate fulfilment of these claims from the Czechoslovak government" 6 .

On October 11, 1938 there was formed the first autonomous government of Subcarpathian Rus', headed by A. Brodi — the leader of the Russophile direction in the region. E. Bachynsky and Y. Revai were appointed as the Ministers ${ }^{7}$. After them, the ministerial post was taken by S. Fentsyk, and A. Voloshyn and I. Pieshchak became state secretaries. The first autonomous government included four representatives of the Russophile and two representatives of the Ukrainian direction. It is necessary to agree with the opinion of modern researchers that the correlation of two to one in favor of 
representatives of Russophilism, really reflected the interrelation between the two main political forces in the region ${ }^{8}$.

Appointment of A. Brodi as Prime Minister was not a surprise either, as he headed a direction, which had a dominant position in the socio-political life of Transcarpathia throughout the interwar period. It should also be noted that since the beginning of its formation in 1923, the Autonomous Agricultural Union (hereinafter referred to as the AZS), headed by A. Brodi, has consistently promoted the main political task - the acquisition of autonomy, which was clearly recorded in the program, so as in the name of the party. In his article "We, the Autonomists, Build a New Free Autonomous Subcarpathian Rus", published in 1935, A. Brodi wrote: "Let me briefly say what do we, the Autonomists, want and what we fight for: Subcarpathian Rus' in its ethnographic borders from Poprad to Tisza, as it is stated in the SaintGermain Peace Treaty and the Constitution of the Czechoslovak Republic... We must know that our aim to live and stay in a large family of peoples will be successful if only we will rule and manage in our own land ourselves. We are fighting for it to this day. Today, power in our land is not in our hands, and we see and feel that we cannot keep the consequences of our work for ourselves. That is why we are fighting for autonomy. Everyone knows, and you already feel that as it has been till now, it can no longer be neither by God, nor by human, nor by natural law"9.

AZS, headed by A. Brodi, has grown dramatically in quantitative terms. In the late 1930's it counted from 5 to 7 thousand members. From year to year the authority of the AZS grew among the population of the region. For example, during the elections to the Czechoslovak parliament in 1924, AZS got 21161 votes $(8,4 \%$ of all voters), in $1925-28799$ votes $(11,6 \%)$, in $1929-48509$ votes $(18,2 \%)$, in $1935-44982$ votes $(13,9 \%)^{10}$.

A. Brodi was authoritative even among part of the exclusively Ukrainian population of mountainous regions. Synevyr priest (Volove District) F. Horvat wrote admiringly in a letter to the owner of the "rus"" printing house Y. Feldeshiy about Brodi's speech in his native village: "Having been sufficiently fed with empty promises, our people, inspired by the speech of deputy Andrej Brodi in our village, were so excited that they had recently stated publicly at the meeting with Soc. Dem. envoy F. Revai: "We don't want any of the Czech parties, and we will support the Autonomous Agricultural Union" $"$.

The autonomous government of A. Brodi held three meetings (October 15, 18, 22-23, 1938). At the first meeting on October 15, 1938 the main governing bodies, consisting of 9 ministries, were considered and approved, it was stated that 170 wagons of corn were imported from Romania to Subcarpathian Rus' in October 1938. At the second meeting, S. Fentsyk reported on the work done during the negotiations on the border marking with Slovakia, and Yu. Revai 
made a report on the ban on the export of state and private property from the territory of the region. Issues of amnesty, cooperation with Germany and others were also discussed. The focus of the third meeting was the internal political situation in Transcarpathia, in particular, there was discussed the issue of a reasonable response to the Hungarian ultimatum regarding the southern territories of the region.

On the initiative of A. Brodi, a commission was formed, which included well-known Transcarpathian scientists P. Sova, H. Herovsky, M. Kondratovych, M. Beskyd and I. Panjkevych, who got a task to prove scientifically that Transcarpathia is a Ruthenian land and with this to "fend off the Magyar demands" 12 . On October 23, 1938, the continuation of the third meeting of A. Brodi's government took place, at which it was decided: "The region of the Rus' people in the south of the Carpathians, marked by peace treaties as an autonomous unit, is one integral whole, parts of which are firmly connected both by the millennial history and by the millennial economic conditions and by fraternal coexistence of its indigenous population... The integrity and inseparability of the region is also recognized by the great allied and friendly states in the international and peace treaties, and the change of its political situation and its belonging we consider to be possible only in its entirety, without the rejection of its southern part from the northern and vice versa, it could be possible solely on the basis of the right of self-determination of all indigenous population by democratic principles: popular vote" ${ }^{\text {"13 }}$. On October 22, 1938 correspondent of Lviv newspaper "Dilo" - part of UNDO in Galicia R. Holian interviewed A. Brodi ${ }^{14}$. A. Brodi and the management of the Autonomous Agricultural Union conducted a double game, focusing on Hungary, which caused dissatisfaction with the representatives of the Ukrainian direction. Newspaper "Nova Svoboda" accused A. Brodi of promoting antiUkrainian actions. The Prime Minister assured that the provocations would be stopped, but they continued. There have been cases of use of force ${ }^{15}$.

It quickly became clear that A. Brodi had worked for a long time in Hungary under the nickname "Bertalon"16. Czechoslovakian counterintelligence closely followed A. Brodi's activities. On January 4, 1933 the head of the Presidium of the police department in Uzhgorod, Herr, reported to the Presidium of the local administration of Subcarpathian Rus' that 'editor Brodi has great ties abroad.., he constantly meets with representatives of the Hungarian opposition forces in Uzhgorod"17. In the encrypted telegram of the Hungarian Foreign Minister K. Kanya to the Hungarian ambassador in Prague, J. Wettstein, there were such instructions about A. Brodi: “...tell Bertalan that he would not in any way obey the Czechs' promises and fully stand on previous positions, that is, with self-determination through plebiscite. Especially pay attention to the fact that if they do not join us, then in this case 
there will be unfavorable economic conditions for them. And if they join us, then these issues will be resolved in a friendly spirit, taking into account their interests. A plebiscite for autonomy within the Hungarian state is the only sensible solution for the Ruthenians... If for any reason there are difficulties in upholding this position, then Bertalan should in all circumstances come to Pest" ${ }^{\prime 18}$.

On October 17, 1938 Y. Revai warned the Minister of Foreign Affairs of the Czechoslovak Republic, F. Khvalkowski, about A. Brodi's ties with Hungary. As a result, the Prague government banned A. Brodi from leaving for Budapest to negotiate with Hungary. Czechoslovakian Minister of Interior Affairs Ya. Chernyi claimed that information from the meetings of the ministerial council goes to the Hungarian Embassy in Prague ${ }^{19}$. The Czechoslovak government accused A. Brodi of violating the "Law on the Protection of the Republic" and arrested him. On October 26, 1938 a newsletter of the Press Service of Carpathian Ukraine reported that "with Brodi there was found a map of Carpathian Ukraine, on which he divided half to the Magyars and half to the Poles, and a lot of money"20. Immediately after his arrest, A. Brodi went on a hunger strike. In prison he was visited by Y. Brashchayko, who gave him a letter, inviting him to accept Hungarian citizenship and leave Czechoslovakia, or stay in it, but for that he had to quit the political activity. A. Brodi rejected these proposals. On February 11, 1939 he was amnestied by the President of the Czechoslovak Republic, E. Hacha, who immediately accepted him and offered to cooperate. However, A. Brodi refused and went to treatment at the Tatra sanatorium. On March 5 he left for Uzhgorod, where his family lived ${ }^{21}$.

It is necessary to agree with the statement of the contemporary Slovak scientist I. Vanat that "in the pre-Munich Czecho-Slovakia the political ruthenianism became the fertile ground for irredentist autonomous political parties of Brodi and Fentsyk, who received support from Hungary and Poland"22. The researcher believes that after the occupation of the region by Hungary, the Horthy regime relied on the representatives of the Russophile direction. Proof of this is the fact that after the occupation of the region by the Hungarian troops, A. Brodi represented Transcarpathia in the Hungarian Parliament. The financing of A. Brodi by the Hungarian government is confirmed by the documents published in Budapest in 1959. Asked by the NKVD investigator on January 13, 1945, "what did you receive from the Hungarian government for your cooperation with them?", A. Brodi replied: “...I received a parliamentary salary of 1500 pengoes, a ministerial pension of 1369 pengoes per month". The resignation and arrest of $\mathrm{A}$. Brodi sparked protests from his supporters, which grew into a mass demonstrations. And A. Brodi's associate S. Fentsyk managed to escape to the Polish Embassy located nearby and then move to Hungary. 
Thus, Andrej Brodi, like all his direction, has undergone a kind of evolution. During the 1920-30s, it was a progressive phenomenon in the social and political life of the region, because it reflected the people's desire for equality within Czechoslovakia. From the late 1930s, it held a clear proHungarian orientation, although his leaders continued to advocate publicly for the unity of Czechoslovakia.

After the arrest of A. Brodi, the Czechoslovakian government appointed A. Voloshyn - the leader of the Ukrainian direction in the land - as the new the Prime Minister ${ }^{23}$. He, in the presence of Minister E. Bachynsky, Czech General O. Swatek and Vice Governor of the region O. Beskyd, swore allegiance to the Czechoslovak Republic. The protocol with the text of the oath was recently published in the collection of documents on Carpathian Ukraine: "The protocol was written on October 26, 1938 in the office of the Minister Dr. Edmund Bachynsky in Uzhgorod on the occasion of the government oath by telephone for the Minister of Subcarpathian Rus' Avgustyn Voloshyn, at the hands of the Leader of the Armada, General Jan Syrovy, in the intercession of the President of the Republic on the basis of paragraph 60 of the Constitutional Charter of the Czechoslovak Republic. Minister of Subcarpathian Rus' Avgustyn Voloshyn at precisely 4.40 pm read the following oath by the phone: "I swear in my honor and consciousness that I will conscientiously and actively fulfil my duties and will take care of the correct implementation of constitutional and other laws". The oath was attended by witnesses of the Division General Oleg Swatek and Vice-Governor of Subcarpathian Rus' Dr. Olexander Beskyd"24.

In a speech on October 26, 1938 A.Voloshyn stated that he would provide "the people of Subcarpathian Rus' with their cultural, national and economic

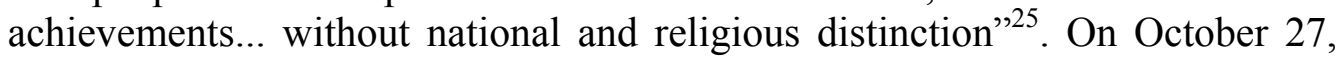
1938, the newspaper "Nova Svoboda" published an invocation of the Ukrainian National Council "To all Ukrainians all over the world! To all Ukrainian parties, organizations, groups, societies in Galicia, Bukovina, Bessarabia, Dnieper Ukraine, Canada, the United States of America, and in general to Ukrainians wherever they reside", which testified to the clear Ukrainian orientation of A. Voloshyn's government: "We believe, - the invocation said, - that the great 50 million Ukrainian people will continue to raise their great word and will not allow our eternal enemies to capture us, to put us in prisons again"26. A. Voloshyn also received a letter from the OUN Executive ${ }^{27}$.

A. Voloshyn formed a new government exclusively from the representatives of the Ukrainian direction. The exception was, perhaps, E. Bachynsky. This caused great dissatisfaction among the representatives of the opposite direction both in the land and abroad. The secretary of the AZS in Presov, V. Dancha, in the letter to A. Voloshyn expressed doubts about the possibility 
of joint actions of the two directions. Voloshyn's response was unambiguous: "We want to live in peace with those people of our kind, who identify themselves as the Rus' camp, when they think of it sincerely, which means that they feel sincerely as Slavs. But with people who, under the cover of Rus', want to join us to Hungary and are agitating for that clearly or through the socalled plebiscite, we do not want to have anything in common with them"28. A. Voloshyn appealed to the representatives of Russophilism for cooperation, but his appeal had a declarative content. Not having their own people in the government, the Russophiles did not agree to the proposed cooperation. We believe that A. Voloshyn's complete distraction in practice from such a mass direction as was Russophile one, was unjustified and erroneous. Instead of making a compromise, the prime minister has stepped up against the opposition $^{29}$.

From the very first days of his premiership, A. Voloshyn began to focus on Germany, hoping for its patronage. As of February 13, 1939 the German national minority of the region was 8714 , or $1,60 \%$ of the population ${ }^{30}$. A. Voloshyn did everything to ensure that the German population did not experience any problems. He even issued an order according to which "all citizens of German nationality, regardless of their state belonging, are allowed to organize themselves in the "German Party" on the national-socialist basis and to organize in this party all the accustomed party bodies, as well as to carry honors and flags with a swastika"31. Engineer E. Oldofredi, as a representative of the German national minority, was included in the list of future ambassadors of the Ukrainian parliament of Transcarpathia on January 27, $1939^{32}$.

The government of Carpathian Ukraine did everything to ensure that relations between Ukrainians and Czechs, who lived in the region, remain neighborly ${ }^{33}$. A. Voloshyn gave a task to the Ministry of Internal Affairs of Carpathian Ukraine, "that in the shortest possible time the normal, friendly relations should be established between the Ukrainian people and the Czech government" ${ }^{\prime 34}$. We should mention that they were greatly exacerbated by the anti-Czech propaganda of the pro-Hungarian "fifth column" in the land, which will be discussed below. Appointing A. Voloshyn as prime minister, the Czechoslovak government had high expectations of him as a moderate politician, hoping for his neutrality in the internal political struggle that had not become weaker in the land. A. Voloshyn was well aware of this when he urged the local population to perform "their duties properly within the Czechoslovak Republic" $"$. Even in the decree on the introduction of the Ukrainian language in the land, it was also suggested to put inscriptions in Czech or Slovak ${ }^{36}$. Thus, the appointment of A. Voloshyn as a Prime Minister did not lead to a radical change in Ukrainian-Czech relations.

As of February 1939, there were 8,5 thousand Czech officials (together with their families - 15 thousand). It is necessary to agree with modern 
researchers that the vast majority of them "treated the power of A. Voloshyn and all Ukrainian with hostility"37, fearing the processes of Ukrainization. Members of the Ukrainian National Council in Velyka Kopania complained to A. Voloshyn about the local commandant of the gendarmerie, J. Krizh, who "makes great trouble in our village, agitated and today is still inciting the population against one candidate's letter" 38 . At the request of V. Kopania residents to leave the village, J. Krizh responded: "I will leave Kopane, but first I have to kill twenty or thirty Ukrainians" 39 . In the village Dovhe "the whole teaching staff is hostile to the Ukrainian nation" ${ }^{\text {"40 }}$. V. Grendzha-Donsky wrote that "the Czechs, not only do sabotages at every step, but even openly agitate. Gendarmerie commander in Bushtyno says openly that with the arrival of the Ukrainian government it will be worse for the population"41. Inhabitants of the village Bilky complained to A. Voloshyn about the local gendarmerie commandant Bogac, who "is a fierce Czech chauvinist, who always treated and still treats the Ukrainian case in a hostile way" ${ }^{\prime 2}$. The authors of the complaint accused Bogac of provocative actions: "...Someone threw a swamp on the Czech inscription on a former Czech kindergarten, where the administration is now located... The windows of the administration chancellery were also thrown over by the swamp. Mr. commandant - soon after the swamp was thrown on the inscription - appeared in the Sich barracks and stated that this act was done by the Sich riflemen... We suspect that it was intentionally prepared to provoke us and defame, that we are against the Czechs"43.

Thus, the vast majority of Czech officials were hostile to the Ukrainian government, which had a negative impact on the development of UkrainianCzech relations ${ }^{44}$. However, it should be noted that often the initiators of antiCzech actions were also the Sich Riflemen. Lawyer M. Bandusyak in his appeal to the investigative commission of the Presidium of Ukrainian Central People's Council wrote that A. Voloshyn's personal secretary I. Rohach "called on the Sich Riflemen to break the windows.., to take away the Czech flags. As a result of this provocation, the Sich Riflemen fought with the soldiers and the police"45. I. Rohach's speeches were a signal to an action. Inhabitant of the village Kolochava, M. Shymonia, told how local Sich Riflemen together with Galicians threw down the Czechoslovak flag and replaced it with Ukrainian. The incident was settled peacefully. Another active participant in the events of 1938-1939, J. Sarvadiy, wrote about the anti-Czech actions by the district commander in Rakhiv, Solomianyi, who ordered to replace the Czech inscriptions with Ukrainian until March 21, 1939. "A local Sich team," wrote J. Sarvadiy, "one night illegally took down the foreign language inscriptions, which caused a misunderstanding with the government. Dr. Fryshchyn publicly disapproved of this endeavor - the Sich Riflemen interfere into other people's affairs. When Dr. Fryshyn was in the ministry of 
education in Khust, he was invited to the Sich's Main Team, where the blanket was thrown over his head and he was beaten so much, that even his ribs were broken" $" 46$.

From the above mentioned it follows that the confrontation into the CzechUkrainian relations was brought by both sides. The Czechs did not accept the Ukrainian authorities and their decisions, and the Ukrainians tried to get rid of the "guardianship", often using different methods, sometimes those that contradicted the Czechoslovak constitution. A. Voloshyn's government has not always been able to control the political situation in the land. Ukrainian-Czech relations worsened after the appointment of the Czech general L. Prchala as the third minister of Carpathian Ukraine. The government of A. Voloshyn treated the decision of the Czech authorities as interfering with the internal affairs of the autonomous state. On January 20, 1939 A. Voloshyn wrote in a letter to L. Prchala: "This violation of the autonomous rights of C.U. (Subcarpathian Rus') caused great outrage among the Carpatho-Ukrainian population. This is evidenced by the swing of demonstrations, which have greatly aggravated the good relations between the Carpatho-Ukrainian population and the Czech government of C.U. ...Cooperation with you in the government of C.U. (SR) in those circumstances is impossible"

Demonstrations against the appointment of L. Prchala as the Ukrainian minister resulted in mass protests in many settlements. Inhabitants of the village Vuchkove sent to the Ukrainian Central People's Council a "Manifesto on life or death", in which they demanded to withdraw L. Prchala, as well as to dismiss all the Czechs from the official positions ${ }^{48}$. There was a protest note from the village Torun: "We will not give the Czechs our freedom, which was once gained with the price of our blood. Only after the death of all of us the Czechs can take our freedom"49. Inhabitants of Kolochava, Richky, Velykyi Studenyi and other Transcarpathian mountain villages demanded an immediate recall of the minister-Czech ${ }^{50}$. It should be noted that some representatives of the government traveled to the villages and called on the masses to protest against the appointment of L. Prchala as Ukrainian minister. On February 5, 1939, Kost Linevych was arrested by Captain Novosad "for attempting to campaign in the village Domanyntsi. He was accused of distributing leaflets against Prchala" ${ }^{\prime \prime 1}$. The case ended in a compromise: L. Prchala performed the duties of the Minister of Transport.

From the above it is evident what was the attitude of the government of Carpathian Ukraine to the Czech and German population, living in the territory of the region. A. Voloshyn tried to implement such a national policy, which would allow all the national minorities to feel at home. The attitude of the Carpatho-Ukrainian government to the Jewish population is a proof of this. According to modern researchers, over 100,000 Jews lived in Transcarpathia at 
the time of Horthy regime's occupation, not counting the unspecified number of those who moved to Slovakia and the Czech Republic before the occupation $^{52}$. On December 28, 1938 A. Voloshyn received a delegation from Jewish national minorities ( $12 \%$ of the total population), whose leaders declared their loyalty to the authorities. In response, the Prime Minister said: "I have always been respectful of Jews, who worship their religion and nationality. The Constitution of the state has not been altered so as to guarantee equal rights for all citizens of the federal state... As for the cultural needs of the Jewish population, they will be provided as much as it is possible"53.

In the late 1930s, Czechoslovakia was a state in which more than thirty different political parties and associations were able to operate freely. All of them represented two main directions - Russophile and Narodovtsi (Ukrainian). One of the most influential was the local organization of the Communist Party of Czechoslovakia (CPC), with close association of the "Union of Labor Peasantry", "The Red Trade Unions", "Left Front" and the "Union of Friends of the USSR". They all stood on the pro-Soviet positions. The Social Democratic Party was very close to the communist one, although it never went closer to it. AZS and the Rus' National-Autonomous Party had Russophile and proHungarian positions. Ukrainian position and position of unification were held by the Ukrainian Central People's Council, the Agrarian Party faction, the Christian People's Party, the cultural and educational organizations "Prosvita", "Plast" and others. This situation existed until October 25, 1938, when the Prague government decided to dissolve the political parties.

Despite this decision by the Czechoslovak government, parties and associations continued to operate. In fact, only the Transcarpathian communists suffered the most because of this action. On October 25, 1938 the ViceGovernor of the region A. Beskyd issued an order to suspend the activities of the regional organization of $\mathrm{CPC}^{54}$. On November 2, 1938 the chief of the Uzhgorod police reported to Prague that, according to the order, "the searches were carried out at the secretariats and apartments of the party leaders in Uzhgorod, Radwanka, and in Domanyntsi", which resulted in "finding and confiscating a written material, seals, certificates and party badges. These things were taken to the police department" organization of CPC were "locked and sealed" 56 .

In 1938 there were four thousand Transcarpathian Communists (they worked in 261 primary organizations of 18 district committees), and in 19391941 they numbered only 61 . The overwhelming majority of members of the regional organization of CPC emigrated to the Soviet Union ${ }^{57}$. A. Voloshyn did not intend to resume the activities of this party; on the contrary, anti-communist propaganda intensified in the region. On the initiative of Transcarpathian nationalists in Carpathian Ukraine, on February 10, 1939, the 
"Society for the Fight against Communism" was formed. At the constituent assembly of this organization, the following leaders were elected: Y. Perevuznyk (chairman), M. Dolynaj (deputy), Yu. Khymynets (secretary) ${ }^{58}$. "The purpose of the society," it was said in the Charter, "is to combat communism and Marxism in all areas of national life and in all its forms, and to eliminate the consequences of Bolshevik-Marxist upbringing. A person, who during the last three years belonged to a society based on Marxist ideology, cannot be accepted" 59 .

On January 20, 1939 the Government of Carpathian Ukraine, "proceeding from a state of public peace and order and the fact that the activities of political parties existing in Carpathian Ukraine (Subcarpathian Rus'), whose activity was discontinued, threatened public (state) security, decided to dissolve all political parties that were active before the above-mentioned decree of the Czechoslovak government. The aftermath of the political party's dissolution... is now upon the announcement. The property of the dissolved political parties, that made up their fund, will be liquidated and the balance will go to the state treasury" 60 . The Transcarpathian press regarded this move by the government as a manifestation of political wisdom: "The political system of Carpathian Ukraine does not know parties. All political parties were dissolved and liquidated. The political leadership of Carpathian Ukraine belongs to the Ukrainian National Council. It is a body of political consolidation and concentration of national forces of Carpathian Ukraine. It is not a political party, though it consists of the active people of all former national-Ukrainian parties. This body is not dominated by any doctrine, only the Ukrainian state-building idea prevails here..."61. The government explained such a departure from democracy in a not very reasoned way: "The people are already clear. In order not to be separated by their enemies, they lost all party affiliation"62.

Dissolving all political parties, A. Voloshyn gave permission to "form a political party called "Ukrainian National Union" (UNO $)^{63}$. The text of the UNO program, signed by 56 political figures of Carpathian Ukraine, was sent for registration by the Ministry of Internal Affairs ${ }^{64}$.

When deciding to dissolve political parties, the government of Carpathian Ukraine made a great juridical mistake, as it meant that all deputies of the dissolved political parties were automatically expelled from the parliament and the Senate of Czechoslovakia. According to V. Shandor, the representative of the government of Carpathian Ukraine in Prague, "all this could be done in another way. The government had to summon all the representatives of political parties, their ambassadors and senators, to present to them a plan on how to arrange the political life of the region and to give them a program of the new political party "Ukrainian National Union". They had to take their position before that. Political parties and their representatives, ambassadors and 
senators who would accept the platform of the new party would join the UNO on behalf of their parties, thereby becoming ambassadors and senators of the new party and retaining their mandates in Prague" $" 65$. The situation was not even saved by the fact that on February 6,1939 the government of Carpathian Ukraine changed its previous decision with a new order. The change meant that the original decree on the dissolution of political parties did not apply to the agrarian, social-democratic, people-socialist and Christian-People's parties. It was the representatives of these parties who formed the backbone of the UNO.

On January 24 a central UNO leadership was appointed, it was headed by UCPC (Ukrainian Central People's Council) chairman F. Revai. Other leadership positions in the party were divided as follows: M. Tulyk - deputy, A. Voron - general secretary, I. Rohach - secretary, V. Grendzha-Donsky editor of the UNO press, V. Komarynsky - propaganda referent, M. Babota and M. Bandusyak - controllers, A. Shtefan, M. Brashchayko, I. Nevytska, S. Rosokha, Y. Pazukhanych, M. Dolynaj, S. Klochurak, V. Lar, D. Nimchuk, M. Marushchak, D. Popovych, I. Klympush, M. Hupalovsky - members of the central leadership of the UNO ${ }^{66}$. Since its inception, the UNO, according to V. Grendzha-Donsky, has begun to make many appeals, which were rather orders $^{67}$. On January 27, 1939 the central leadership of the UNO formed a list of candidates for ambassadors to the Soim of Carpathian Ukraine, which included 32 persons. According to the contemporary, the selection of candidates was made hastily and unsuccessfully ${ }^{68}$. But the vast majority of them were members of UNO. The formation of UNO testified that the government of Carpathian Ukraine could not completely abandon the existence of parties. Secondly, it testified to a certain independence of the Ukrainian authorities, which by the decree on the formation of the UNO violated previous decisions of the Prague authorities.

On February 8, 1939 the government of Carpathian Ukraine appealed to the citizens in connection with the elections to the Soim ${ }^{69}$. On February 8, 1939 "Nova Svoboda" published an appeal by Orthodox believers to the population urging them to vote for the UNO ${ }^{70}$. The Government of Carpathian Ukraine paid the utmost attention to the propaganda work, which was described in detail by S. Rosokha ${ }^{71}$. The leaflet propaganda has especially intensified on the eve of the elections to the Soim. All the leaflets urged to vote for the $\mathrm{UNO}^{72}$.

It should be noted that some political forces have made their candidate lists for the Soim. In particular, the deputies of the Prague parliament from the former agrarian party and the "Group of Subcarpathian Ruthenians" did this way, but the Central Election Commission denied them. This act of A. Voloshyn's government should be regarded as a significant violation of the basic democratic rights of the local population. The government made every effort to convince the population in a short time of the need to vote for the 
UNO, although there was no opposite political party and the elections were held on a non-alternative basis. It seemed that the government would not allow new parties to be formed in the near future. This idea was the leading idea in the vast majority of leaflets. "You are already united," one of them said, "and you can never break into parties and groups again"73. On February 10, the AllUkrainian People's Council's address to the Ukrainian people was read on the radio, which ended with a call: "Ukrainian people! We are experiencing a historic moment. The star of freedom has dawned on us. The Ukrainian case came to a wide political forum. The whole world is looking at us. Let's be wise, strong, careful. Fewer words - more action! Everyone at your place do your duty! And the planned teamwork, organization and obedience will give us invincible power" ${ }^{\prime 74}$.

The elections to the Soim were scheduled for February 12, 1939. An eyewitness wrote that "the result of Sunday's elections... was so extremely successful and useful to the Ukrainian people and Ukrainians in general, that it impressed with its surprise not only the enemies but also the friends of Carpathian Ukraine" ${ }^{95}$. Of the $92,5 \%$ of the population who took part in the elections, $92,4 \%$ voted in favor of the UNO. The elections were conducted at a satisfactory level without significant disruption, and their consequences can be considered credible ${ }^{76}$. The newsletter of the Press Service of Carpathian Ukraine conveyed the impression of a German journalist: "I had to travel through many villages, which had a white flag (that is, $98 \%$ voted for UNO Aut.). I could see peasants staring with enthusiasm at that piece of cloth and looking at me, as if they wanted to say: "You see our pride, stranger". You must be proud of the national consciousness of your people" "77. On February 14, 1939 A. Voloshyn addressed the population of the autonomous region in connection with the victory of the UNO Party in the elections to the Soim of Carpathian Ukraine ${ }^{78}$.

It should be noted that a number of settlements gave a majority of their votes against the UNO. In particular, the inhabitants of the villages Iza, Hudya, Verbovets, Smoholovytsia, Ruski Komarivtsi, Velyki Lazy, Bukovets, Dusyno, Pasika, Vyshnia Roztoka did so. More than two thousand votes against the UNO were recorded in the capital of Carpathian Ukraine - Khust. This evidences to the fact that people were free to express their opinions. At the same time, it proves that the Ukrainian idea was set in an uncompromising struggle of opposing forces.

According to Constitutional Law No. 328 of November 22, 1938, which legalized the autonomous status of the region, elections and the Soim of Carpathian Ukraine were envisaged. It defined the chronological framework for holding the first regional parliament the next way: "The Soim of Carpathian Ukraine will be elected no later than April 1939 and convened a month after 
elections by the President of the Republic to the city designated by the Carpatho-Ukrainian authorities"79. The government of A. Voloshyn planned to hold the opening of the Soim in Rakhiv on March 2, 1939, but the President of the Czechoslovak Republic E. Hacha did not convene a session that day. A special postage stamp was even issued for this solemn event. The attempt to open the Soim on March 9 in Khust was also unsuccessful. E. Hacha allowed to convene the Soim of Carpathian Ukraine on March 21, 1939, but at A. Voloshyn's request he changed the date to March 15. Members of the government of Carpathian Ukraine, as a rule, accused Prague of permanently postponing the Soim. However, it should be noted that according to the Constitutional Law of November 22, 1938 there were no legal violations by the Czechoslovak authorities.

On March 14, 1939 A. Voloshyn declared independence of Carpathian Ukraine $^{80}$. On the same day, A. Voloshyn sent a telegram to German Minister of Foreign Affairs J. Ribbentrop, stating: "In the name of the Government of Carpathian Ukraine, I request you to take note of the declaration of our independence under the protection of the German Reich" ${ }^{\prime 1}$. Representative to the Czechoslovak Government, V. Shandor, was asked to "carry out the act of independence in Prague, and here we will do what will be necessary" V. Shandor also informed the USA diplomatic mission in Prague about the declaration of independence of Carpathian Ukraine: "After Slovakia declared full independence, the Czech-Slovak Republic ceased to exist. Therefore, Carpathian Ukraine has declared itself completely independent on the basis of the Munich decisions concerning the right of self-determination of the Carpatho-Ukrainian people, as well as through the Vienna Arbitration. The Carpatho-Ukrainian people want the German nation's leader and the government of the German state not to refuse the sovereign protection of independence of Carpathian Ukraine" ${ }^{, 83}$.

This decision was undoubtedly influenced by factors of an international situation, in particular, the declaration of independence by Slovakia and the invasion of Hungarian troops into the territory of Carpathian Ukraine. These factors testified to the state breakup of the Czechoslovak Republic. Six sessions of the Soim, which took place over the course of three hours in one day, were destined to be historical, because during them the documents of historical weight had been given - on independence, state structure, name, language, flag, emblem and anthem of Carpathian Ukraine.

The Soim was opened by Avgustyn Voloshyn: "Bright Soim! From the bottom of my heart I feel the importance of the words that I gave to you as the first lawfully elected political representation of our people. On this occasion, I am experiencing the most momentous minute of my life... We will build Carpathian Ukraine, with recognition of full rights of the national minorities, to make all citizens of Carpathian Ukraine feel happy..." ${ }^{\text {, }}$. 
The Head of the Soim of Carpathian Ukraine was elected A. Shtefan, who delivered a vivid speech: "...In the history of the Ukrainian people, it was not yet the case that a legislative body was chosen by popular vote. Laws were issued by Ukrainian kniazs, kings and hetmans, but one thing the past does not know - legislative Soim, elected with the will of the people. For many centuries, the Ukrainian people wandered in the dark and waited for a better fortune, for freedom. But only when the fall of 1938 came, did our people come into a mighty breakdown and started bravely a new path to the open spaces of freedom.

And we, representatives of Carpathian Ukraine, elected by our people, without hesitation we become where we are assigned. Because the right and power are given to us not by violence, not by party intrigues, not by bounding one against the other, not by Judas money, but by the unanimous, spontaneous will of the Ukrainian people in Carpathian Ukraine.

We want to believe that the unbreakable will of the Ukrainian people - to live their free lives - will be respected by all cultural peoples, for whom the principle of peoples self-determination is a holy covenant and not an empty phrase. For it is the audacity to think that the Almighty has created this world for only one or two nations. Every nation has a holy right to live its own life in this world. The Ukrainian nation is not a guest in Carpathian Ukraine!..

I believe that the First Ukrainian Soim of CU will continue the started work the way that our long-suffering people will rejoice with their freedom, their truth. I ask the Almighty to allow the First Ukrainian Soim of the CU to serve the interests of the Ukrainian people" 85 .

Delegates unanimously adopted the text of constitutional law Part 1:

1. Carpathian Ukraine is an independent State.

2. The name of the State is: Carpathian Ukraine.

3. Carpathian Ukraine is a Republic, headed by the President, elected by the Soim of Carpathian Ukraine.

4. The official language of Carpathian Ukraine is Ukrainian.

5. The colors of the national flag of Carpathian Ukraine are blue and yellow, whereby the blue color is up and the yellow is down.

6. The state emblem of Carpathian Ukraine is the regional emblem: a bear in the left red semicircle, four blue and three yellow stripes in the right semicircle and the Trident of St. Volodymyr the Great with a cross on the middle tooth. The transfer of this place of law is left to a separate law.

7. The national anthem of Carpathian Ukraine is "Shche ne wmerla Ukraina" ("Ukraine has not died yet").

8. This law is now working since its adoption ${ }^{86}$.

The president was elected by secret voting. A. Voloshyn became the president, all ambassadors voted for him. 
The Soim took place at a time when the Hungarian army had already invaded the territory of Carpathian Ukraine. The young independent state stopped its existence without starting any activity. However, despite the short duration of its existence, the very emergence of Carpathian Ukraine as a state has once again demonstrated to the whole world that there are Ukrainians living in Transcarpathia who wish to have their statehood together with their brothers from Greater Ukraine. This is confirmed by the "Proclamation of the All-Ukrainian People's Council to all Ukrainian people", adopted on February 10, 1939: "The Ukrainian people... we firmly believe that in the new great battle the Ukrainian nation will heroically win and will stand with its strong foot on the thousand-year-old mountains of the Golden-domed, shined with the sun of freedom, Saint Kyiv!" ${ }^{87}$. The idea of the unification of all Ukrainian lands is the key idea in a memorandum of the delegation of Carpathian Ukraine to the Chancellor of Germany on October 24, 1938. "Carpathian Ukraine", it is noted there, "is the part of the territory of the Ukrainian people. Therefore, its population is aware of the responsibilities that it faces at the moment, not only in relation to their country, but also to all the Ukrainians" ${ }^{\prime 88}$. However, these intentions were not destined to come true.

Thus, the internal political development of Carpathian Ukraine from September 1938 to mid-March 1939 was ambiguous, controversial and complex. The greatest success of the political forces of the region was the acquisition of autonomous rights within the federal Czechoslovakia. The replacement of A. Brodi's cabinet by A. Voloshyn's government testified to a radical change in political orientation. Beginning in October 1938, A. Voloshyn and his government led a clear course on the Ukrainianization of all social life in Carpathian Ukraine. The Ukrainian government of Transcarpathia clearly adhered to the orientation towards Germany, the only country that guaranteed the security of the borders of the region.

An important milestone in the life of the Transcarpathians was the elections and sessions of the Soim of Carpathian Ukraine - the first Ukrainian parliament in the land. Despite the historicity of the decisions taken by the Soim, they were formal, because the occupation of Carpathian Ukraine by Hungary did not enable them to be implemented.

The difficult internal political situation in Carpathian Ukraine, which was simultaneously negatively affected by internal and external factors, as well as A. Voloshyn's uncertainty in the comprehensive support of the whole population of the region, made him move to a certain curtailment of democratic processes. It manifested itself in the prohibition of all political parties and the creation of a single party - UNO, which testified to the authoritarian nature of power in Carpathian Ukraine. The departure of A. Voloshyn's government from democracy was explained by the need to create optimal conditions for the 
consolidation of all patriotic forces of Carpathian Ukraine and for the socioeconomic transformation in the region.

${ }^{1}$ Разгулов В. Дело № 148423. Карпатская панорама. 1995. 20 января, 26 сентября, 30 августа.

2 Шандор В. Спомини. Т. 1. Карпатська Україна. 1938-1939. Ужгород: МПП «Гражда»; Карпатський Союз, 1996. С. 152.

3 Шандор В. Спомини. Т. 1. Карпатська Україна. 1938-1939. Ужгород: МПП «Гражда»; Карпатський Союз, 1996. С. 151.

${ }^{4}$ Ibid. C. 152.

${ }^{5}$ Разгулов В. Дело № 148423. Карпатская панорама. 1995. 20 января, 26 сентября, 30 августа; Лемак В. «Відкидаємо спосіб обманювання всього світу...». Американські русини і проблема вирішення автономії Підкарпатської Русі 20-30-х років. Карпатський край. 1995. № 9-12. С. 62-65; Лемак В. Через призму демократії. Хуст над Тисою. Ужгород, 1992. С. 38-43; Лемак В.В. Карпатська Україна і Німеччина в 1938-1939 роках. Матеріали наукової конферениії. Ужгород, 1993. С. 46-55; Лемак В.В. Сойм Карпатської України. Події березня 1939 р. Нариси історії Закарпаття. Ужгород, 1995. Т. 2. C. 310-317.

${ }^{6}$ Карпатська Україна. Документи і матеріали. Хроніка подій. Персоналії: У 2-х томах. Том 1. Карпатська Україна. Документи і матеріали. Упорядники: О.Д. Довганич, О.М. Корсун, О.М. Пагіря; редакційна колегія: М.А. Попович (голова), О.Д. Довганич (заст. голови), М.М. Вегеш, М.В. Делеган, В.К. Дрогальчук, О.М. Корсун, І.Ю. Коршинський, О.Ю. Кучерява, О.М. Пагіря, С.Д. Федака; редактор Д.М. Федака. Ужгород: ВАТ «Видавництво «Закарпаття», 2009. С. 60-61.

7 Державний архів Закарпатської області (далі - ДАЗО). Ф. 3. Оп. 1. Спр. 38. Арк. 1.

${ }^{8}$ Болдижар М. Закарпаття між двома світовими війнами. Ужгород, 1993. С. 79.

${ }^{9}$ Разгулов В. Дело № 148423. Карпатская панорама. 1995. 20 января, 26 сентября, 30 августа.

${ }^{10}$ Ibid.

${ }^{11}$ Особистий архів о. Феодосія Горвата.

12 ДАЗО. Ф. 3. Оп. 1. Спр. 40. Арк. 3.

13 ДАЗО. Ф. 3. Оп. 1. Спр. 40. Арк. 3.

${ }^{14}$ Нова свобода. 1938. 20 жовтня.

${ }^{15}$ Гренджа-Донський В. Щоденник. Твори. Т. VIII. Вашингтон, 1987. С. 30.

${ }^{16}$ Болдижар М. Закарпаття між двома світовими війнами. Ужгород, 1993. С. 81.

${ }^{17}$ ДАЗО. Ф. 3. ОП. 2. Спр. 6. Арк. 3.

18 Карпатська Україна. Документи і матеріали. Хроніка подій. Персоналії: У 2-х томах. Том 1. Карпатська Україна. Документи і матеріали. Упорядники: О.Д. Довганич, О.М. Корсун, О.М. Пагіря; редакційна колегія: М.А. Попович (голова), О.Д. Довганич (заст. голови), М.М. Вегеш, М.В. Делеган, В.К. Дрогальчук, О.М. Корсун, І.Ю. Коршинський, О.Ю. Кучерява, О.М. Пагіря, С.Д. Федака; редактор Д.М. Федака. Ужгород: ВАТ «Видавництво «Закарпаття», 2009. С. 59.

19 Шандор В. Спомини. Т. 1. Карпатська Україна. 1938-1939. Ужгород: МПП «Гражда»; Карпатський Союз, 1996. С. 155.

${ }^{20}$ ДАЗО. Ф. 2. Оп. 1. Спр. 209. Арк. 28. 
${ }^{21}$ Федака С.Д. Андрій Бродій (1895-1946). Карпатська Украӥна. Документи і матеріали. Хроніка подій. Персоналії: У 2-х томах. Том 2. Карпатська Україна. Хроніка подій. Персоналії. Упорядник С.Д. Федака; редакційна колегія: I.I. Качур (голова), М.М. Вегеш, О.Д. Гаврош, М.В. Делеган, В.І. Дмитрук, О.Д. Довганич, В.К. Дрогальчук, О.М. Корсун (заст. голови), І.Ю. Коршинський, Ю.В. Мойш, М.В. Олашин, О.М. Пагіря, С.Д. Федака; редактор Д.М. Федака. Ужгород: ПРАТ «Видавництво «Закарпаття», 2010. С. 164.

${ }^{22}$ Ванат I. Чи русини самобутній народ? Пам'ятки України. 1992. № 1. С. 20; Ванат I. Нариси новітньої історії українців Східної Словаччини. Книга перша (1918-1938). Пряшів, 1979. 364 с.

${ }^{23}$ ДАЗО. Ф. 3. Оп. 3. Спр. 47. Арк. 12.

${ }^{24}$ Карпатська Україна. Документи і матеріали. Хроніка подій. Персоналії: У 2-х томах. Том 1. Карпатська Україна. Документи і матеріали. Упорядники: О.Д. Довганич, О.М. Корсун, О.М. Пагіря; редакційна колегія: М.А. Попович (голова), О.Д. Довганич (заст. голови), М.М. Вегеш, М.В. Делеган, В.К. Дрогальчук, О.М. Корсун, І.Ю. Коршинський, О.Ю. Кучерява, О.М. Пагіря, С.Д. Федака; редактор Д.М. Федака. Ужгород: ВАТ «Видавництво «Закарпаття», 2009. С. 82.

25 ДАЗО. Ф. 3. Оп. 3. Спр. 47. Арк. 9.

${ }^{26}$ Нова свобода. 1938. 27 жовтня.

${ }^{27}$ Басараб В., Вегеш М., Сергійчук В. Августин Волошин. Нові документи і матеріали про життя і смерть президента Карпатської України. Ужгород: Видавництво УжНУ «Говерла», 2006. С. 41-44.

28 ДАЗО. Ф. 3. ОП. 3. Спр. 41. Арк. 1.

29 Болдижар М. Про статус Закарпаття: історичні факти і домисли. Закарпаття 6 складі Чехословаччини: Проблеми відродження $i$ національного розвитку: Доповіді наукового семінару, присвяченого 80-ій річниці утворення Чехословаччини. 28 жовтня 1998 р. Ужгород, 1999. С. 23-24; Болдижар М., Болдижар С. Державність на Закарпатті: події, факти, оцінки. Ужгород, 2003. 212 с.; Болдижар М., Болдижар С. Державність на Закарпатті: правда історії та вигадки фальсифікаторів. Перші кроки. Ужгород, 2004. 136 с.; Болдижар М., Лемак В. Уряд Августина Волошина і його державно-правова діяльність у Карпатській Україні (жовтень 1938 - березень 1939 рр.). Молодь-Украӥні: Наукові записки молодих учених Ужгородського державного університету. Ужгород: Закарпатський центр соціальної служби для молоді, 1994. Т. 4. С. 284-296; Болдижар М., Мосні П. Державно-правовий статус Закарпаття (Підкарпатської Русі) в складі Чехословаччини. Ужгород, 2002. 240 с.; Болдижар М., Панов А. Державність Закарпаття в політикоправовій діяльності Т. Масарика. Ужгород: Закарпаття, 2005. 104 с.; Болдижар С., Мойш В. Автономія Підкарпатської Русі як передумова проголошення Карпатської України. Карпатська Україна - незалежна держава. Матеріали Міжнародної наукової конференції, присвяченої Незалежності Карпатської України (м. Ужгород, 14-15 березня 2019 року). Вступне слово В. Смоланки; Редкол.: М. Вегеш (голова), С. Віднянський, М. Лендьел, О. Пагіря, М. Токар, С. Федака (члени редкол.). Ужгород: видавництво ПП «АУТДОР-ШАРК», 2019. С. 171-177.

${ }^{30}$ ДАЗО. Ф. 3. Оп. 2. Спр. 8. Арк. 1.

31 ДАЗО. Ф. 3. ОП. 1. Спр. 45. Арк. 4.

32 Гренджа-Донський В. Щоденник. Твори. Т.VIII. Вашингтон, 1987. С. 144.

33 Вегеш М. Августин Волошин і Карпатська Україна. Дзвін. 1991. № 3. С. 85-90; Вегеш М. Августин Волошин і Карпатська Україна. Львів: ЗУКЦ, 2004. 414 с.; Вегеш М. Августин Волошин: Зміна орієнтацій. Пороги (Прага, Чеська Республіка). 1997. № 2. С. 21-22, № 3. С. 19-20.

${ }^{34}$ ДАЗО. Ф. 3. ОП. 3. Спр. 64. Арк. 60-62. 
35 ДАЗО. Ф. 3. Оп. 3. Спр. 47. Арк. 9.

36 ДАЗО. Ф. 3. ОП. 3. Спр. 10. Арк. 5.

37 Богів О. Карпатська Україна (Підкарпатська Русь) і політика європейських держав в радянській історіографії (1944-1991 рр.). Закарпатська Украӥна: 1945 рік: Матеріали наукової конференції, присвяченої 50-річчю Перемоги над фашизмом та 50-річчю возз'єднання Закарпаття з Україною. 26 травня 1995 р. Ужгород: Патент, 1995. С. 78-91.

38 ДАЗО. Ф. 3. ОП. 2. Спр. 28. Арк. 1.

39 ДАЗО. Ф. 3. ОП. 2. Спр. 28. Арк. 2.

40 ДАЗО. Ф. 3. ОП. 3. Спр. 55. Арк. 32.

${ }^{41}$ Гренджа-Донський В. Щоденник. Твори. Т.VIII. Вашингтон, 1987. С. 117.

42 ДАЗО. Ф. 17. Оп. 2. Спр. 21. Арк. 3.

43 ДАЗО. Ф. 17. Оп. 2. Спр. 21. Арк. 4.

${ }^{44}$ Вегеш М. Історичні дослідження: Закарпаття між двома світовими війнами. Ужгород, 2000. T. IV. 339 с.; Вегеш М. Історичні дослідження: Історія Карпатської України (1938-1939). Ужгород, 2000. Т. І. 311 с.; Вегеш М. Історичні дослідження: Історія Карпатської України (1938-1939). Ужгород, 2000. Т. II. 282 с.; Вегеш М. Історичні монографії та дослідження: Закарпаття в контексті центральноєвропейської політичної кризи напередодні Другої світової війни. Київ-Ужгород: Колір Прінт, 1998. Т. І. 380 с.; Вегеш М. Історія і політика: В 4-х томах. Т. 2. Історія Карпатської України. Августин Волошин - президент Карпатської України. Будівничі Карпатської України. Василь Гренджа-Донський розповідає... Ужгород, 2005. 552 с.

${ }^{45}$ ДАЗО. Ф. 1148. Оп. 1. Спр. 2. Арк. 3.

46 Сарвадій Й. Змова проти уряду Карпатської України. Ужгород: Карпатський Союз, 1984. С. 14.

${ }^{47}$ ДАЗО. Ф. 3. Оп. 3. Спр. 64. Арк. 42, 44.

${ }^{48}$ ДАЗО. Ф. 3. ОП. 3. Спр. 178. Арк. 42.

49 ДАЗО. Ф. 3. Оп. 3. Спр. 78. Арк. 48.

50 ДАЗО. Ф. 3. Оп. 3. Спр. 78. Арк. 44, 106, 115

${ }^{51}$ ДАЗО. Ф. 3. Оп. 3. Спр. 10. Арк. 3.

52 Макара М. Гнані долею (Етно-соціальний нарис історії єврейства на Закарпатті). Карпатський край. 1995. №9-12. С. 14.

${ }^{53}$ Ibid. C. 16.

54 Росоха С. Сойм Карпатської України. Вінніпег, 1949; Львів: Меморіал, 1990. C. 34-35.

${ }^{55}$ ДАЗО. Ф. 3. ОП. 4. Спр. 12. Арк. 1.

${ }^{56}$ ДАЗО. Ф. 3. ОП. 4. Спр. 12. Арк. 2.

${ }^{57}$ Болдижар М. Закарпаття між двома світовими війнами. Ужгород, 1993. С. 123.

58 ДАЗО. Ф. 3. Оп. 4. Спр. 12. Арк. 3.

59 ДАЗО. Ф. 3. Оп. 4. Спр. 13. Арк. 13.

${ }^{60}$ Ibid. C. 50.

${ }^{61}$ Болдижар М. Закарпаття між двома світовими війнами. Ужгород, 1993. С. 93.

${ }^{62}$ ДАЗО. Ф. 3. ОП. 2. Спр. 5. Арк. 5,6.

63 ДАЗО. Ф. 3. ОП. 2. Спр. 5. Арк. 7.

${ }^{64}$ Карпатська Україна. Документи і матеріали. Хроніка подій. Персоналії: У 2-х томах. Том 1. Карпатська Україна. Документи і матеріали. Упорядники: О.Д. Довганич, О.М. Корсун, О.М. Пагіря; редакційна колегія: М.А. Попович (голова), О.Д. Довганич (заст. голови), М.М. Вегеш, М.В. Делеган, В.К. Дрогальчук, О.М. Корсун, І.Ю. Коршинський, О.Ю. Кучерява, О.М. Пагіря, С.Д. Федака; редактор Д.М. Федака. Ужгород: ВАТ «Видавництво «Закарпаття», 2009. С. 182-190. 
65 Шандор В. Спомини. Т. 1. Карпатська Україна. 1938-1939. Ужгород: МПП «Гражда»; Карпатський Союз, 1996. С. 158.

${ }_{67}^{66}$ ДАЗО. Ф. 3. Оп. 2. Спр. 6. Арк. 8.

${ }^{67}$ ДАЗО. Ф. 3. Оп. 2. Спр. 13. Арк. 168.

${ }^{68}$ Гренджа-Донський В. Щоденник. Твори. Т.VIII. Вашингтон, 1987. С. 108.

${ }^{69}$ Карпатська Україна. Документи і матеріали. Хроніка подій. Персоналії: У 2-х томах. Том 1. Карпатська Україна. Документи і матеріали. Упорядники: О.Д. Довганич, О.М. Корсун, О.М. Пагіря; редакційна колегія: М.А.Попович (голова), О.Д. Довганич (заст. голови), М.М. Вегеш, М.В. Делеган, В.К. Дрогальчук, О.М. Корсун, І.Ю. Коршинський, О.Ю. Кучерява, О.М. Пагіря, С.Д. Федака; редактор Д.М. Федака. Ужгород: ВАТ «Видавництво «Закарпаття», 2009. С. 212.

${ }^{70}$ Ibid. C. 222.

71 Росоха С. Сойм Карпатської України. Вінніпег, 1949; Львів: Меморіал, 1990. C. $31-40$.

${ }^{72}$ Нова свобода. 1939. 15 лютого.

73 ДАЗО. Ф. 3. Оп. 3. Спр. 64. Арк. 163.

74 Карпатська Україна. Документи і матеріали. Хроніка подій. Персоналії: У 2-х томах. Том 1. Карпатська Україна. Документи і матеріали. Упорядники: О.Д. Довганич, О.М. Корсун, О.М. Пагіря; редакційна колегія: М.А.Попович (голова), О.Д. Довганич (заст. голови), М.М. Вегеш, М.В. Делеган, В.К. Дрогальчук, О.М. Корсун, І.Ю. Коршинський, О.Ю. Кучерява, О.М. Пагіря, С.Д. Федака; редактор Д.М. Федака. Ужгород: ВАТ «Видавництво «Закарпаття», 2009. С. 227.

${ }_{75}$ ДАЗО. Ф. 4c/18. ОП. 1. Спр. 34. Арк. 1.

${ }_{77}^{76}$ ДАЗО. Ф. 17. Оп. 2. Спр. 376. Арк. 1.

${ }_{77}^{7 А}$ ДАО. Ф. 3. Оп. 3. Спр. 64. Арк. 163.

78 Карпатська Україна. Документи і матеріали. Хроніка подій. Персоналії: У 2-х томах. Том 1. Карпатська Україна. Документи і матеріали. Упорядники: О.Д. Довганич, О.М. Корсун, О.М. Пагіря; редакційна колегія: М.А. Попович (голова), О.Д. Довганич (заст. голови), М.М. Вегеш, М.В. Делеган, В.К. Дрогальчук, О.М. Корсун, І.Ю. Коршинський, О.Ю. Кучерява, О.М. Пагіря, С.Д. Федака; редактор Д.М. Федака. Ужгород: ВАТ «Видавництво «Закарпаття», 2009. С. 230.

79 ДАЗО. Ф. 3. Оп. 4. Спр. 12. Арк. 4.

80 Карпатська Україна. Документи і матеріали. Хроніка подій. Персоналії: У 2-х томах. Том 1. Карпатська Україна. Документи і матеріали. Упорядники: О.Д. Довганич, О.М. Корсун, О.М. Пагіря; редакційна колегія: М.А.Попович (голова), О.Д. Довганич (заст. голови), М.М. Вегеш, М.В. Делеган, В.К. Дрогальчук, О.М. Корсун, І.Ю. Коршинський, О.Ю. Кучерява, О.М. Пагіря, С.Д. Федака; редактор Д.М. Федака. Ужгород: ВАТ «Видавництво «Закарпаття», 2009. С. 276.

${ }^{81}$ Ibid.

82 Шандор В. Спомини. Т. 1. Карпатська Україна. 1938-1939. Ужгород: МПП «Гражда»; Карпатський Союз, 1996. С. 269.

${ }^{83}$ Карпатська Україна. Документи і матеріали. Хроніка подій. Персоналії: У 2-х томах. Том 1. Карпатська Україна. Документи і матеріали. Упорядники: О.Д. Довганич, О.М. Корсун, О.М. Пагіря; редакційна колегія: М.А.Попович (голова), О.Д. Довганич (заст. голови), М.М. Вегеш, М.В. Делеган, В.К. Дрогальчук, О.М. Корсун, І.Ю. Коршинський, О.Ю. Кучерява, О.М. Пагіря, С.Д. Федака; редактор Д.М. Федака. Ужгород: ВАТ «Видавництво «Закарпаття», 2009. С. 277.

${ }^{84}$ Росоха С. Сойм Карпатської України. Львів: Меморіал, 1991. С. 61-62.

${ }^{85}$ Росоха С. Сойм Карпатської України. Львів: Меморіал, 1991. С. 68-70. 
${ }^{86}$ Карпатська Україна. Документи і матеріали. Хроніка подій. Персоналії: У 2-х томах. Том 1. Карпатська Україна. Документи і матеріали. Упорядники: О.Д. Довганич, О.М. Корсун, О.М. Пагіря; редакційна колегія: М.А.Попович (голова), О.Д. Довганич (заст. голови), М.М. Вегеш, М.В. Делеган, В.К. Дрогальчук, О.М. Корсун, І.Ю. Коршинський, О.Ю. Кучерява, О.М. Пагіря, С.Д. Федака; редактор Д.М. Федака. Ужгород: ВАТ «Видавництво «Закарпаття», 2009. С. 278-279.

${ }^{87}$ ДАЗО. Ф. 3. Оп. 2. Спр. 32. Арк. 4.

${ }^{88}$ ДАЗО. Ф. 3. Оп. 3. Спр. 14. Арк. 1.

\section{REFERENCES}

1. Basarab, V., Vehesh, M., \& Serhiichuk, V. (2006). Avhustyn Voloshyn. Novi dokumenty $i$ materialy pro zhyttia $i$ smert prezydenta Karpatskoi Ukrainy. Uzhhorod: Vydavnytstvo UzhNU Hoverla [in Ukrainian].

2. Bohiv, O. (1995). Karpatska Ukraina (Pidkarpatska Rus) i polityka yevropeiskykh derzhav v radianskii istoriohrafii (1944-1991 rr.). Zakarpatska Ukraina: 1945 rik: Materialy naukovoi konferentsii, prysviachenoi 50-richchiu Peremohy nad fashyzmom ta 50-richchiu vozziednannia Zakarpattia z Ukrainoiu. 26 travnia 1995 r. Uzhhorod: Patent [in Ukrainian].

3. Boldyzhar, M. (1993). Zakarpattia mizh dvoma svitovymy viinamy. Uzhhorod [in Ukrainian].

4. Fedaka, S.D. (2010). Andrii Brodii (1895-1946). Karpatska Ukraina. Dokumenty $i$ materialy. Khronika podii. Personalii. (Vol.2). Uzhhorod: PRAT Vydavnytstvo Zakarpattia [in Ukrainian].

5. Hrendzha-Donskyi, V. (1987). Shchodennyk. Tvory. (Vol.8). Vashynhton [in Ukrainian].

6. Karpatska Ukraina. Dokumenty $i$ materialy. Khronika podii. Personalii. (2009). (Vol.1). Uzhhorod: VAT Vydavnytstvo Zakarpattia [in Ukrainian].

7. Makara, M. (1995). Hnani doleiu (Etno-sotsialnyi narys istorii yevreistva na Zakarpatti). Karpatskyi krai, 9-12 [in Ukrainian].

8. Razghulov, V. (1995). Delo №148423. Karpatskaia panorama. 20 yanvaria, 26 sentiabria, 30 avhusta [in Russian].

9. Rosokha, S. (1990). Soim Karpatskoi Ukrainy. Lviv: Memorial [in Ukrainian].

10. Sarvadii, Y. (1984). Zmova proty uriadu Karpatskoi Ukrainy. Uzhhorod: Karpatskyi Soiuz [in Ukrainian].

11. Shandor, V. (1996). Spomyny. (Vol.1). Uzhhorod: MPP Hrazhda; Karpatskyi Soiuz [in Ukrainian].

12. Vanat, I. (2006). Chy rusyny samobutnii narod? Pamiatky Ukrainy, 1 [in Ukrainian]. 